\title{
Investigation of Secondary School Students' Predispositionto Physical Education and Their Levels of Responsibility for Learning
}

\author{
Mustafa Baş ${ }^{*}$, Elif Aydin² \\ ${ }^{1}$ Department of Sport Sciences, Trabzon University, Trabzon, \\ Turkey \\ ${ }^{2}$ School of Physical Education and Sports, Gümüşhane University, \\ Gümüşhane, Turkey
}

Study Area: Trabzon, Turkey

Coordinates: $41^{\circ} \mathrm{oo}^{\prime} 18^{\prime \prime} \mathrm{N} ; 39^{\circ} 43^{\prime} 21^{\prime \prime} \mathrm{E}$

Key words: Inclination to Physical Education, Elearning, Information technologies

\section{Abstract}

The study was carried out on a total of 260 secondary education students, 135 (51.9\%) female and 125 (48.1\%) male. As data collection tools in research, the "Personal Information Form", the "Physical Education Predisposition Scale" and the "Responsibility to Learn Scale" were used. Considering the relationship between students' predispositions to physical education and their level of responsibility for learning, it was found that there was a positive significant relationship between the responsibility and the attitude and self-efficacy. Following the regression analysis a positive relationship between the students' level of responsibility for learning and their attitude and selfefficacy was found. In this context, it can be stated that as the students' levels of responsibility for learning increase, their level of predisposition to physical education also increases. The equation for students' levels of responsibility for learning to predict their predisposition to physical education is significant.

behaviours in sports fields. However, the individual must have a positive attitude and self-efficacy towards the lesson in order to reach the benefits of physical education and sports lessons in different development areas. Attitude and self-efficacy towards physical education and sports lesson are expressed with the concept of predisposition. Sports activities help the individual gain awareness of social responsibility. It also helps individuals participating in sports activities to be responsible in their professional life (Yetim, 2005). Sportive activities have positive implications for social development as well as physical development. In addition, individuals develop the awareness of being active, taking responsibility and undertaking the results of the responsibilities they take. They find the opportunity to express their interests and values through their behaviour (Çakmakçi, 2001). Responsibility is defined by many researchers as being aware of one's own actions and behaviours, accepting and undertaking the positive or negative consequences created by their behaviour (Özen, 2013). A sense of responsibility is the feeling of fulfilling the undertaken or given task in whatever situation and taking on the consequences associated with it (Yontar \& Yurtal, 2009).

Learning responsibility is a concept that has an important place in students' academic success and educational life. Sportive activities not only improve through physical education and sport lessons prepares the ground for displaying more moral 
students' predisposition to physical education lessons, but also increase their motivation for learning, improve their responsibility for learning, and facilitate success in their lessons. The concept of responsibility gains importance for students in determining whether students' behaviour is appropriate or not, directing the result by taking their own responsibility for not being passive in the learning-teaching process and controlling the learning stages on their own. The predisposition of students to physical education, determination of their responsibilities towards learning and providing the necessary pieces of training have made it necessary to handle them with importance as issues that need to be emphasized in achieving the aims of our education system. Thus this study is proposed to examine the secondary school students' predisposition to physical education and their level of responsibility for learning.

\section{Materials and Methods:}

A total of 26o secondary education students, 135 (51.9\%) female and 125 (48.1\%) male, from two different secondary schools determined in the district of Akçaabat in Trabzon province in the fall semester of the academic year 20192020. As data collection tools in research, the "Personal Information Form" prepared by the researcher, the "Physical Education Predisposition Scale" developed by Hilland et al. (2009) and adapted into Turkish by Öncü et al., (2015) and the "Responsibility to Learn Scale" developed by Yakar \& Saracaloğlu (2017) were used.

The "Physical Education Predisposition Scale" developed by Hilland et al. (2009) and adapted into Turkish by Öncü et al. (2015) was used to determine students' attitudes and self-efficacy towards physical education. The scale consists of 11 items and has a 2 -factor structure. The factors were named as "attitude" (6 items) and "selfefficacy" ( 5 items). Statements 1, 6 and 11 in the scale were reverse scored. Expressions on the scale are "5-point Likert Type Scale". The "Responsibility to Learn Scale" used in the study was developed by Yakar \& Saracaloğlu (2017) to measure students' responsibilities. In the reliability calculation, the Cronbach Alpha internal consistency coefficient of the scale consisting of 35 items for internal consistency was calculated as 93. It was also stated that all items of the scale were collected in one dimension. In the research, the survey model, one of the quantitative research designs, was used. SPSS 25 .oo program was used to analyze the research data. In addition, T-test, one-way ANOVA, correlation and regression analysis were used for data analysis, and the significance level was taken as 0.05.

\section{Results:}

The skewness and kurtosis coefficients of the students' scores from the "Physical Education Predisposition Scale" and "Responsibility to Learn Scale" were established between -1.5 and +1.5 , and data were observed to be distributed normally (Tabachnick \& Fidell, 2013).
Table-1: T-test results of students' levels of predisposition to physical education \& responsibility for learning as per the gender

\begin{tabular}{lllllll}
\hline Sub-dimensions & Gender & $\mathrm{N}$ & & $\mathrm{Sd}$ & $\mathrm{t}$ & $\mathrm{p}$ \\
\hline Attitude & Female & 135 & 3.51 & 0.47 & 0.758 & 0.449 \\
& Male & 125 & 3.46 & 0.52 & & \\
Self-efficacy & Female & 135 & 3.26 & 0.44 & 2.156 & $.032^{*}$ \\
& Male & 125 & 3.13 & 0.5 & & \\
Responsibility & Female & 135 & 3.56 & 0.28 & -1.834 & 0.068 \\
& Male & 125 & 3.62 & 0.2 & & $<.05^{*}$
\end{tabular}

In the elf-efficacy $(\mathrm{t}=2.156 ; \mathrm{p}<.05)$ sub-dimension, $\mathrm{a}$ difference was found in favor of girls (Table-1).

Table-1: T-test results of students' levels of predisposition to physical education and responsibility for learning as per the licensed Sports Category

\begin{tabular}{|c|c|c|c|c|c|c|}
\hline \multicolumn{2}{|c|}{ Sub-dimensions Sports Ct. } & \multicolumn{2}{|l|}{$\mathrm{N}$} & \multirow{2}{*}{$\begin{array}{l}\mathrm{Sd} \\
0.51\end{array}$} & \multirow{2}{*}{$\frac{t}{-3.112}$} & \multirow{2}{*}{$\begin{array}{l}\mathrm{p} \\
.002^{*}\end{array}$} \\
\hline Attitude & Team & 137 & 3.4 & & & \\
\hline \multirow{3}{*}{ Self-efficacy } & Individual & 123 & $3 \cdot 59$ & 0.45 & & \\
\hline & Team & 137 & 3.21 & 0.45 & 0.435 & 0.664 \\
\hline & Individual & 123 & 3.18 & 0.5 & & \\
\hline \multirow[t]{2}{*}{ Responsibility } & Team & 137 & 3.5 & 0.27 & -6.254 & $.000^{*}$ \\
\hline & Individual & 123 & 3.68 & 0.17 & & \\
\hline
\end{tabular}

In the sub-dimensions of attitude and responsibility, a difference was found in favor of individual sports (Table-2).

Table-3: One-Way ANOVA Results of Students' Physical Education Predisposition and Responsibility for Learning As per the Sports Background

\begin{tabular}{|c|c|c|c|c|c|c|}
\hline Sub-dimen. & Sports & $\mathrm{N}$ & & $\mathrm{Sd}$ & $\mathrm{Sd}$ & $\mathrm{F}$ \\
\hline \multirow[t]{4}{*}{ Attitude } & o-1 year & 69 & 3.63 & 0.44 & 3 & $6.623 .000^{*}$ \\
\hline & 2-3years & 67 & 3.59 & 0.37 & 256 & \multirow{3}{*}{$\begin{array}{l}\text { Tukey- } \\
>6^{*}\end{array}$} \\
\hline & 4-5years & 70 & 3.39 & 0.55 & 259 & \\
\hline & >6years & 54 & $3 \cdot 3$ & 0.53 & & \\
\hline \multirow[t]{4}{*}{ Self-efficacy } & o-1 year & 69 & $3 \cdot 54$ & 0.52 & 3 & $33.695^{2-3} \cdot 000^{*}$ \\
\hline & 2-3years & 67 & $3 \cdot 31$ & 0.42 & 256 & \multirow{3}{*}{$\begin{array}{l}\text { Tukey- } \\
\text { o-1* } \\
2-3 / 4-5 />6\end{array}$} \\
\hline & 4-5years & 70 & 3 & 0.26 & 259 & \\
\hline & >6years & 54 & 2.89 & 0.36 & & \\
\hline \multirow[t]{4}{*}{ Responsibility } & o-1year & 69 & 3.68 & 0.26 & 3 & $4.501 \quad .002$ * \\
\hline & 2-3years & 67 & $3 \cdot 55$ & 0.14 & 256 & \multirow{3}{*}{$\begin{array}{l}\text { Tukey- } \\
\text { o-1* } \\
2-3 / 4-5\end{array}$} \\
\hline & 4-5years & 70 & $3 \cdot 54$ & 0.32 & 259 & \\
\hline & >6 years & 54 & $3 \cdot 57$ & 0.19 & & \\
\hline
\end{tabular}

As per the multiple comparison test (post-hoc) results, in the attitude sub-dimension, there is a significant difference between 6 years and above and o-1 year and 2-3 years in favour of o-1 year; in the self-efficacy subdimension, there is a significant difference between o-1 year and 2-3 years, 4-5years and 6 years and above in favour of o-1 years; in the responsibility sub-dimension, there is a difference between 0-1 year and 2-3 years and 4-5 years in favour of o-1 year (Table-3).

Table-4: The Relationship between Students' Predisposition to Physical Education and their Levels of Responsibility for Learning

\begin{tabular}{llll}
\hline Sub-dimensions & Attitude & Self-efficacy & Responsibility \\
\hline Attitude & 1 & & \\
Self-efficacy & $.54^{* *}$ & 1 & \\
Responsibility & $.60^{* *}$ & $.49^{* *}$ & 1
\end{tabular}


A positive and significant relationship between responsibility, and attitude and self-efficacy. In this context, it can be stated that as students' levels of responsibility for learning increase, their levels of predisposition to physical education also increase (Table-4).

Table-5: The Prediction Level of Students' Levels of Responsibility for Learning to Their Predisposition to Physical Education

\begin{tabular}{llllll}
\hline Variable & $\mathrm{B}$ & St. Error & $\mathrm{B}$ & $\mathrm{t}$ & $\mathrm{p}$ \\
\hline Constant & 2.358 & .096 & & 24.573 & .000 \\
Attitude & .239 & .029 & .472 & 8.206 & .000 \\
Self-efficacy & .124 & .030 & .237 & 4.116 & .000 \\
\hline $\mathrm{R}=.632 \mathrm{a}$ & $\mathrm{R} 2=.399$ & $\mathrm{~F}=85.365$ & &
\end{tabular}

As a result of the regression analysis, was a positive relationship between students' levels of responsibility for learning and attitude and self-efficacy (Table-5).

\section{Discussion:}

A significant difference was found in the physical education predisposition and responsibility levels of students in terms of "attitude", "self-efficacy" and "responsibility" subdimensions according to their sports background. Therefore, it can be said that individuals who participate in sports for 0-1 years display a better attitude and are more self-sufficient and responsible than others, develop a positive attitude towards physical education lesson, and participate willingly in physical education lessons. Since the scores of students, who participate in sports between o1 year, are higher than the scores of the students who participate in sports between 2-3 years 4-5years and 6 years and above, it can be said that their levels of predisposition to physical education also increase as their levels to cope with different situations and conditions, believe in success and have responsibility increase. Considering the relationship between students' predisposition to physical education and their levels of responsibility for learning, it was found that there was a positive and significant relationship between responsibility, and attitude and selfefficacy. In this context, it can be stated that as the students' levels of responsibility for learning increase, their levels of physical education predisposition also increase. The equation for students' levels of responsibility for learning to predict their physical education predisposition is significant. As a result of the regression analysis, it was found that there is a positive relationship between students' levels of responsibility for learning, and attitude and selfefficacy.

While the levels of physical education predisposition and responsibility for learning differ significantly in the "attitude" and "responsibility" sub-dimensions according to the sports category, there was no significant difference in the other sub-dimension. A difference was found in favour of individual sports in attitude and responsibility subdimensions. Turan (2020), found that in the sports branch variable, the mean scores of the students participating in team sports were significantly higher than the mean scores of the students participating in individual sports, and in the sports branch variable, no significant difference was found between the students' predisposition to physical education and attitude scores. In their study on athletes and nonathletes students studying in secondary education, Asci et al. (1993) did not find a significant difference in the athletic competence and global competence sub-dimensions of the students engaged in sports in football, basketball, volleyball, handball and track and field branches. Gökçe \& Arslan (2014) with the participation of 338 athletes reported the self-efficacy levels of athletes participating in the individual sports branch were higher than the athletes participating in team sports. In the study on 50 athletes, Kishore (2016) reported that there is no significant difference between the self-efficacy levels of athletes participating in individual and athletes participating in team sports. Studies conducted in the literature are not similar to research findings. In the study in which these branches were not evaluated due to the low, the number of students participating in bocce and athletics branches, Hazar (2019) did not detect a significant difference in the mean scores of the attitude of students, who actively participated in sports in football, volleyball, basketball, wrestling, taekwondo and table tennis branches, for the physical education.

In the "self-efficacy" sub-dimensions of physical education predisposition levels, a significant difference was found in favor of girls according to gender. The first study using the scale developed by Hilland et al. (2009), Fairlough et al. (2012) was on the motivational predisposition of adolescent girls in north-west England to physical education class and at the end of the study, it was determined that the motivational predisposition of adolescent girls was positive. It is observed that there are many factors affecting students' attitudes towards both physical activities and physical education lesson and physical education studies have focused on these factors (Subramaniam and Silverman, 2007). When the studies in the literature were examined, it was found that the selfefficacy levels of secondary school students engaged in sports were significantly higher than the self-efficacy scores of male students according to the gender variable in some studies (Akbulut, 2017; Şengül 2016; Pauline 2013; Singetal., 2009). In the study by Turan (2020), it was found that male students 'self-efficacy scores were significantly higher than female students' self-efficacy scores in the gender variable. Regarding the gender variable, it is seen that secondary school students have a highly positive attitude for physical education and sports lessons. It is thought that situations that enable secondary school students participating in school sports to have a high level of positive attitude towards physical education can be the benefits such as loving sports, releasing their energies, doing activities with 
their friends outdoors.

It is expected that athlete students' predisposition to physical education will be at a higher level. For this, the attitude levels of students can be increased by making physical education lessons more bright and fun. In addition, individual differences can be taken into account to improve self-efficacy levels, and lessons can be taught in line with the participation method. The study can be handled qualitatively. The research can be carried out on athlete students with different sports experience. The study can be done with different variables that are thought to affect motivation and learning responsibility. This study shows that it can be used to determine the value that secondary school students in the field of physical education in Turkey give to physical education lessons and their perceived abilities for physical education lessons.

In the "self-efficacy" sub-dimensions of physical education predisposition levels, a significant difference was found in favour of girls according to gender. The first study using the scale developed by Hilland et al. (2009), Fairlough et al. (2012) was on the motivational predisposition of adolescent girls in north-west England to physical education class and at the end of the study, it was determined that the motivational predisposition of adolescent girls was positive. It is observed that there are many factors affecting students' attitudes towards both physical activities and physical education lesson and physical education studies have focused on these factors (Subramaniam \& Silverman, 2007). When the studies in the literature were examined, it was found that the self-efficacy levels of secondary school students engaged in sports were significantly higher than the self-efficacy scores of male students according to the gender variable in some studies (Akbulut, 2017; Șengül 2016; Pauline 2013; Sing et al., 2009). Turan (2020), found that male students 'self-efficacy scores were significantly higher than female students' self-efficacy scores in the gender variable. Regarding the gendervariable, it is seen that secondary school students have a highly positive attitude for physical education and sports lessons. It is thought that situations that enable secondary school students participating in school sports to have a high level of positive attitude towards physical education can be the benefits such as loving sports, releasing their energies, doing activities with their friends outdoors.

It is expected that athlete students' predisposition to physical education will be at a higher level. For this, the attitude levels of students can be increased by making physical education lessons more bright and fun. In addition, individual differences can be taken into account to improve self-efficacy levels, and lessons can be taught in line with the participation method. The study can be handled qualitatively. The research can be carried out on athlete students with different sports experience. The study can be done with different variables that are thought to affect motivation and learning responsibility. This study shows that it can be used to determine the value that secondary school students in the field of physical education in Turkey give to physical education lessons and their perceived abilities for physical education lessons.

\section{References:}

Akbulut, V. (2017): Öğretmen liderlik stiline göre ortaokul öğrencilerinin beden eğitimi yatkınlıklarının incelenmesi. (Yüksek lisans tezi). Karadeniz Teknik Üniversitesi, Eğitim Bilimleri Enstitüsü, Trabzon.

Akpinar, B. (2011): Eğitim Programları ve Öğretim. Pub. by: Data Yayınları, Ankara.

Așçı, F.H., Gökmen, H., Tiryaki, G. \& Öner, U. (1993): Liseli erkek sporcuların ve sporcu olmayanların benlik kavramları. Spor Bilimleri Dergisi, 4(1):34-43.

Bakanlığı, M.E. (2009): MEB 2010-2014 stratejik plani. TC Milli Eğitim Bakanlığı.

Baymur, F. (1994): Genel Psikoloji. Pub. by: İnkilap Kitabevi, İstanbul.

Çakmakçı, S. (2001): Okullarda Beden Eğitimi Dersi Faaliyetlerinin Öğrencilerin Sosyalleşmesine Etkileri. Yüksek Lisans tezi, Dumlupınar Üniversitesi Sosyal Bilimler Enstitüsü, Kütahya.

Fairclough, S., Hilland, T.A., Stratton, G. \& Ridgers, N. (2012): 'Am I able? Is it worth it?' Adolescent girls' motivational predispositions to school physical education: Associations with health-enhancing physical activity. Eur. Phy. Edu. Rev., 18(2),:147-158.

Gökçe, H. \& Arslan, Y. (2014): Comparison of the athletes' self efficacy: participating to individuals or team sports. Conference: International Scientific Conference, Effects Of Physical Activity Application To Anthropological StatusWith Children, Youth, And Adults. at Belgrade, Serbia.

Hazar, G. (2019): Ortaöğretim öğrencilerinin beden eğitimi dersine karşı tutumlarını etkileyen faktörlerin araștırılması. (Yüksek lisans tezi). Selçuk Üniversitesi, Sağlık Bilimleri Enstitüsü, Konya.

Hilland, T.A., Stratton, G., Vinson, D. \& Fairclough, S. (2009): The physical education predisposition scale: Preliminary development and validation. L. Sports Scie, 27(14):1555-1563.

Kishore, V. (2016): Comparative study of self-efficacy between individual and team game players. Int. J. Appl. Res., 2(12):565566.

Öncü, E., Gürbüz, B., Küçük Kılıç, S., \& Keskin, N. (2015): Psychometric properties of the Turkish version of the physical education predisposition scale. In: ERPA International Health and Sports Science Education Congress (p. 179).

Özen, Y. (2013): Sorumluluk Duygusu Ölçeğinin Geliștirilmesi; Geçerlikve Güvenirliği.J.Eur. Edu., 3(2):17-23.

Pauline, J.S. (2013): Physical activity behaviours, motivation, and self-efficacy among college students. Coll. Student J., 7(1):6474 .

Singh, T.D., Bhardwaj, G. \& Bhardwaj, V. (2009): Effect of selfefficacy on the performance of athletes. J. Exer. Sci. Physioth., 


\section{ORIGINAL ARTICLE}

5(2):110-114.

Subramaniam, P.R. \& Silverman, S. (2007): Middle school students' attitudes toward physical education. Teach. Teacher Edu., 23:602-611.

Tabachnick, B. \& Fidell, L. (2013): Using Multivariate Statistics (6th International edition cover). Pub. by: Sage Publications, Thousand Oaks, New Jersey.

Turan, S. (2019): Okul Sporlarına Katılan Ortaöğretim Öğrencilerinin Beden Eğitimine Yatkınlıkları ve Beden Eğitimi Dersindeki Sportmenlik Davranışlarının İncelenmesi. Doktora tezi. Sakarya Uygulamalı Bilimler Üniversitesi, Lisansüstü Eğitim Enstitüsü.
Ambient Science, 2020: Vol. 07(Sp1); 355-359 DOI:10.21276/ambi.2020.07.sp1.oa47

Yakar, A. \& Saracaloğlu, A.S. (2017): Öğrenmeye yönelik sorumluluk ölçeği. Mehmet Akif Ersoy Üniversitesi Eğitim Fakültesi Dergisi, (42), 27-49.

Yetim, A.A. (2005): Sosyoloji ve Spor. Pub. by: Morpa Kültür Yayınları, İstanbul.

Yontar, A. \& Yurtal, F. (2009): Sorumluluk Kazandırmada Öğretmenler Tarafından Kullanılan Yaptırımların İncelenmesi. Eğitim ve Bilim, 1300-1337. 